\title{
Documents related with the life of the National Academy of Medicine
}

Martha Eugenia Rodríguez-Pérez

Co-editor, Gaceta Médica de México

The idea of presenting the "About the life of the Academy" section in Gaceta Médica de Mexico goes back to 1864 and persists in the $20^{\text {th }}$ century. In the Gaceta first number, Dr. Carlos Alberto Ehrmann, chairman of the Scientific Commission Medical Section, which later would be named National Academy of Medicine, evinced the need for this section because the original works did not occupy all moments of the corporation at its first year of life; there were also writings that complied with the guidelines of the grouping. With the passage of time, documents related to the life of the Academy were increased, including speeches from incoming and outgoing presidents, reviews of academic works, calls for annual prizes and rulings, among others. Therefore, rescuing this section is justified by virtue of the fact that the National Academy of Medicine of Mexico is a corporation dedicated to the promotion of study, teaching and research in the field of medicine since 154 years ago, in addition to being a federal government advisory body. That antiquity and that complex activity lead to resuming this section, which will frame different documents, including the speeches delivered in solemn sessions.
Gac Med Mex. 2018;154:349-349

Contents available at PubMed www.gacetamedicademexico.com 